\title{
Ground-motion simulation for the eastern province of Saudi Arabia using a stochastic model
}

\author{
M. S. Fnais \\ Geology \& Geophysics Department, Faculty of Science, \\ King Saud University, Riyadh, Saudi Arabia
}

\begin{abstract}
The eastern Arabian Peninsula lies close to Zagros fold-thrust fault belt that has been considered as one of the most active seismotectonic regions in the Middle East, where the occurrences of large earthquakes $\left(\mathrm{M}_{\mathrm{w}} \geq 5.0\right)$ are in abundance. The southern Kuwait seismic zone is the nearest source to the study area. Hence, a wide spread damage can be expected in this region due to the presence of thick section of soft sediments. Here earthquake catalogue is compiled, reviewed precisely and compared with the international seismological data. The affected seismotectonic zones are modeled and their seismicity parameters and maximum moment magnitude are estimated. Peak Ground Acceleration values for earthquakes with magnitudes $4.0 \leq \mathrm{M}_{\mathrm{w}} \leq 7.5$ have been simulated at distances up to $300 \mathrm{~km}$ from the source using a stochastic model. The predicted attenuation for Peak Ground Acceleration (PGA) at bedrock is estimated as: log (PGA) = $-0.94+0.249 \mathrm{M}_{\mathrm{w}}-\log \mathrm{r}-0.00233 \mathrm{r}+0.19 \mathrm{P}$. With the help of this equation, the potential seismic hazard for the eastern part of the Arabian Peninsula can be assessed.
\end{abstract}

Keywords: ground motion simulation, stochastic, seismicity, seismotectonic zones, eastern province.

\section{Introduction}

The Eastern province of Saudi Arabia becomes one of the important zones throughout Saudi Arabia where important commercial and densely populated cities are located. In addition, the strategic petroleum industries are of utmost importance to national and international interest. The area has experienced (June 
2, 1993) an earthquake of magnitude 4.8, which occurred in the Minagish oil field (southwest of Kuwait) and was widely felt with panic in the city of Kuwait. This area was struck again by earthquakes on September 1997 (M 3.9) and December 30, 1997 (M 4.2). While in January 2002 a moderate earthquake (M 5.2) shook the Musandam Peninsula at the border between Oman and the United Arab Emirates. In November 1945, a significant earthquake of $\mathrm{M}=8.1$ originated from Makran subduction zone, (located at the southeastern end of the Arabian plate boundary) and affected the eastern province of Saudi Arabia. Convergence between the Arabian and Eurasian tectonic plates commonly originates damaging earthquakes, where the events instigated by the subduction zone are the most destructive (Kanamori [1]). This historical background reveals that a potential for wide-spread damage as a result of future destructive earthquakes cannot be noted ruled out in the tangent area.

\section{Geologic setting of Eastern Saudi Arabia}

A sequence of continental and shallow marine sediments extends along the Arabian Gulf with relatively low-relief terrain in which Tertiary and younger deposits cover the older units. The Upper Cretaceous and Eocene rocks represented by limestone and dolomite, while Quaternary sequences are made from sandstone, sandy marl, and sandy limestone of non-marine origin (Fig. 1).

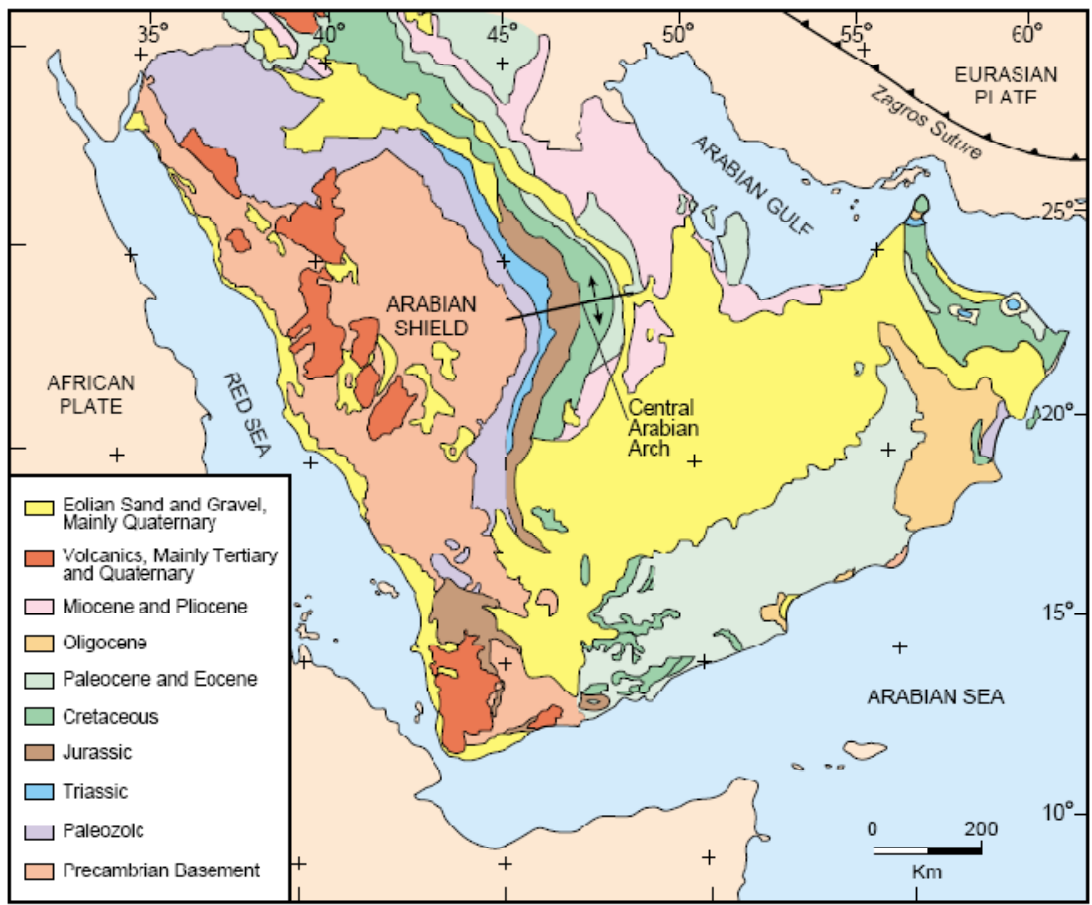

Figure 1: $\quad$ Generalized geology of the Arabian Peninsula (USGS [3]). 
These sequences dip gently towards the east and northeast below the thrusting of the Zagros Mountains (Al-Sayari and Zoetl [2]). The Umm er Radhuma Formation of Paleocene and lower Eocene age forms a wide belt extending $\sim 1200 \mathrm{~km}$ from south to north with a width of $60-120 \mathrm{~km}$. The middle part of the belt is covered with eolian sand. The exposures of the Umm er Radhuma Formation forms a gently undulating but rough surface with low altitude isolated hills and benches. Outcrops of the Dammam Formation of lower and middle Eocene age are restricted to the Arabian Gulf coastal region.

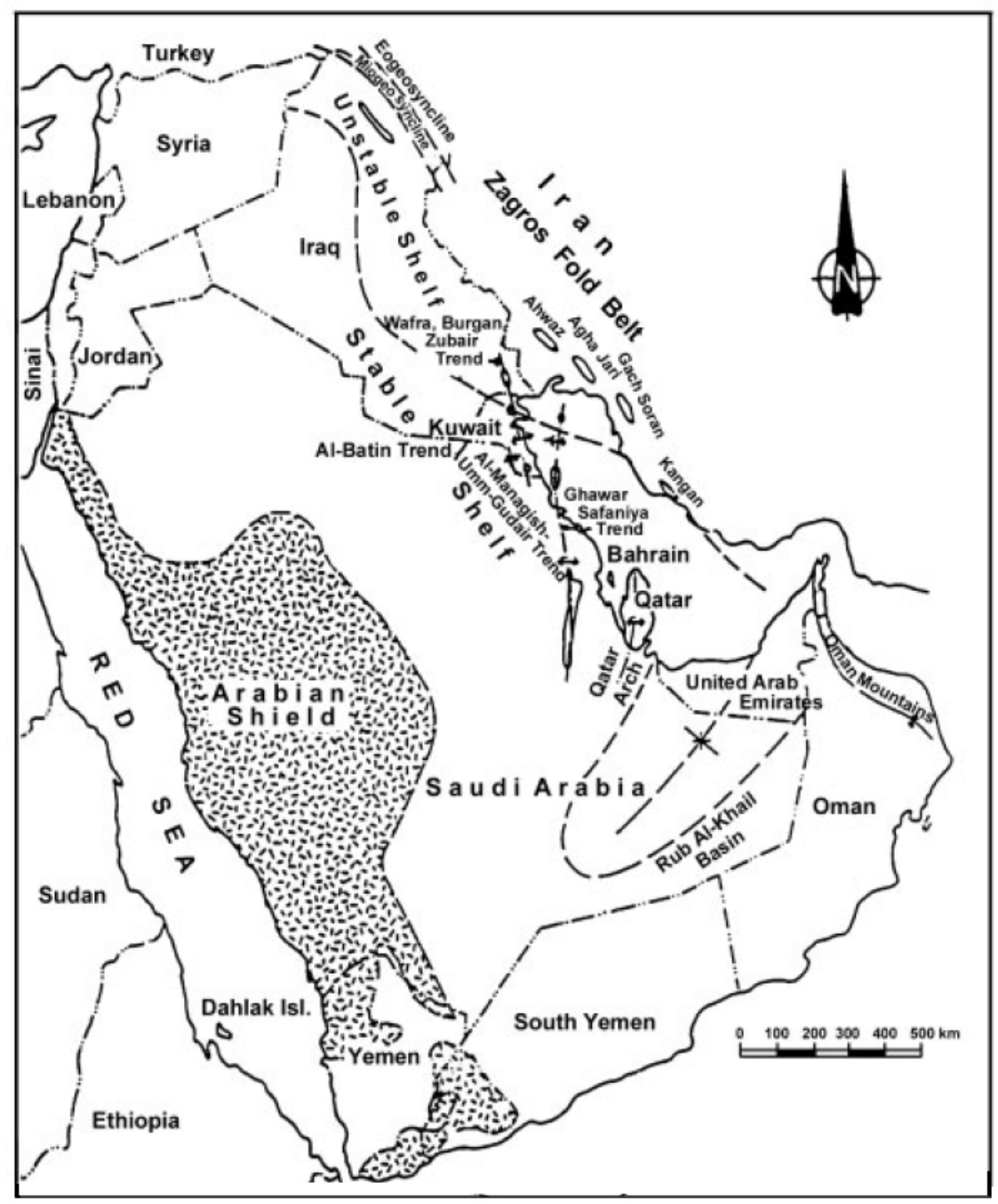

Figure 2: $\quad$ Major tectonic units of the Arabian Gulf Region (Clarke [4]). 
Tectonics of the eastern province is dominated by a collision between the Arabian Plate and the Eurasian Plate along Zagros and Bitlis Thrust belt. Five major tectonic episodes controlled the tectonostratigraphy of the Upper Cambrian and Phanerozoic sedimentary successions in the Arabian Plate. Clarke [4] stated that number of N-S trending fault terrains, such as the Summan Platform, the Khurais-Burgan trend, the Ghawar trend and the Qatar Arch trend are distributed through the area of interest. These great anticlines are bounded by the orthogonal NE-SW trending (Wadi Batin) and NW-SE trending (Abu Jifan) strike-slip faults (Fig. 2).

\section{Seismicity of Saudi Arabia}

Number of low to moderate magnitude events originated from the eastern province of Saudi Arabia and the Zagros Thrust Fault belt have been recorded through the recently deployed seismic stations. Most earthquakes occurred in the crustal part of the Arabian Plate beneath the Zagros Belt. Large earthquakes (M $\geq 5$ ) are quite common along this fault and a potential for destructive earthquakes with wide-spread damage cannot be ruled out in future. The Zagros Belt is a prolific source for number of earthquakes with magnitude $(M \geq 7)$ occurred in the past decades. According to Al-Shaabi [5], about 69 instrumentally recorded earthquakes $(2.4<\mathrm{Ml}<5.8)$ have been occurred during the period between 1990 and 1998, which clustered around the southeastern flank of Ghawar anticlinal structure.

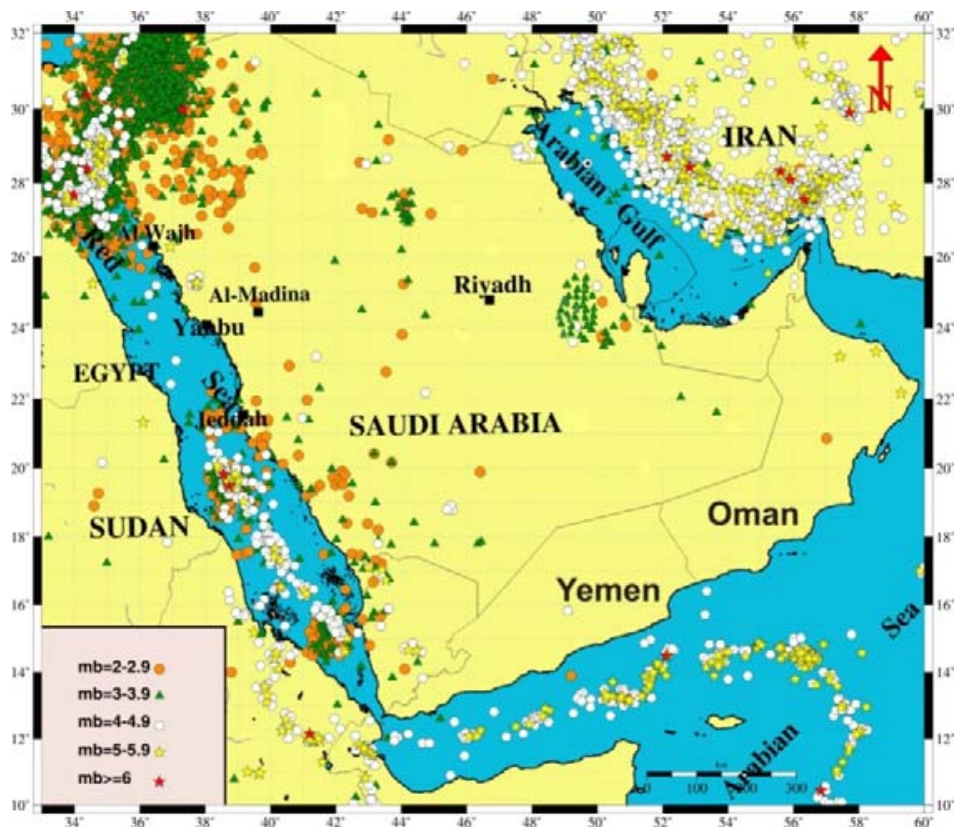

Figure 3: $\quad$ Seismicity map for the Arabian Peninsula (1900 up to Dec. 2010). 


\subsection{Earthquakes data resources}

For present study, the earthquake data have been obtained from different sources, i.e., Seismic Studies Center (SSC) of King Saud University, Saudi Geological Survey (SGS); Kuwait National Seismological Network (KNSN). The collected data are merged, precisely reviewed, re-analyzed and refined from duplicated events through the International Seismological Center (ISC); United States Geological Survey (USGS); and the European Mediterranean Seismological Center (EMSC). Different magnitude scales are unified and converted into moment magnitude using Scordilis [6] relation. Finally, spatial distribution of the compiled seismicity catalogue is plotted to construct new seismicity map for the Arabian Plate and adjacent area (Fig.3). The reliability and quality of earthquake data sources have been investigated before their use for the catalogue compilation. Foreshock and aftershock sequences have been removed from the catalogue using the windowing procedure proposed by Gardner and Knopoff [7].

\subsection{Identification of seismotectonic source zones}

Depending on the distribution of earthquakes, geological structures and previous seismotectonic studies (Al-Amri, [8]; Tavakoli, [9] and Pascucci et al. [10]), seven of seismogenic source zones can be differentiated (Fig. 4 and table 1).

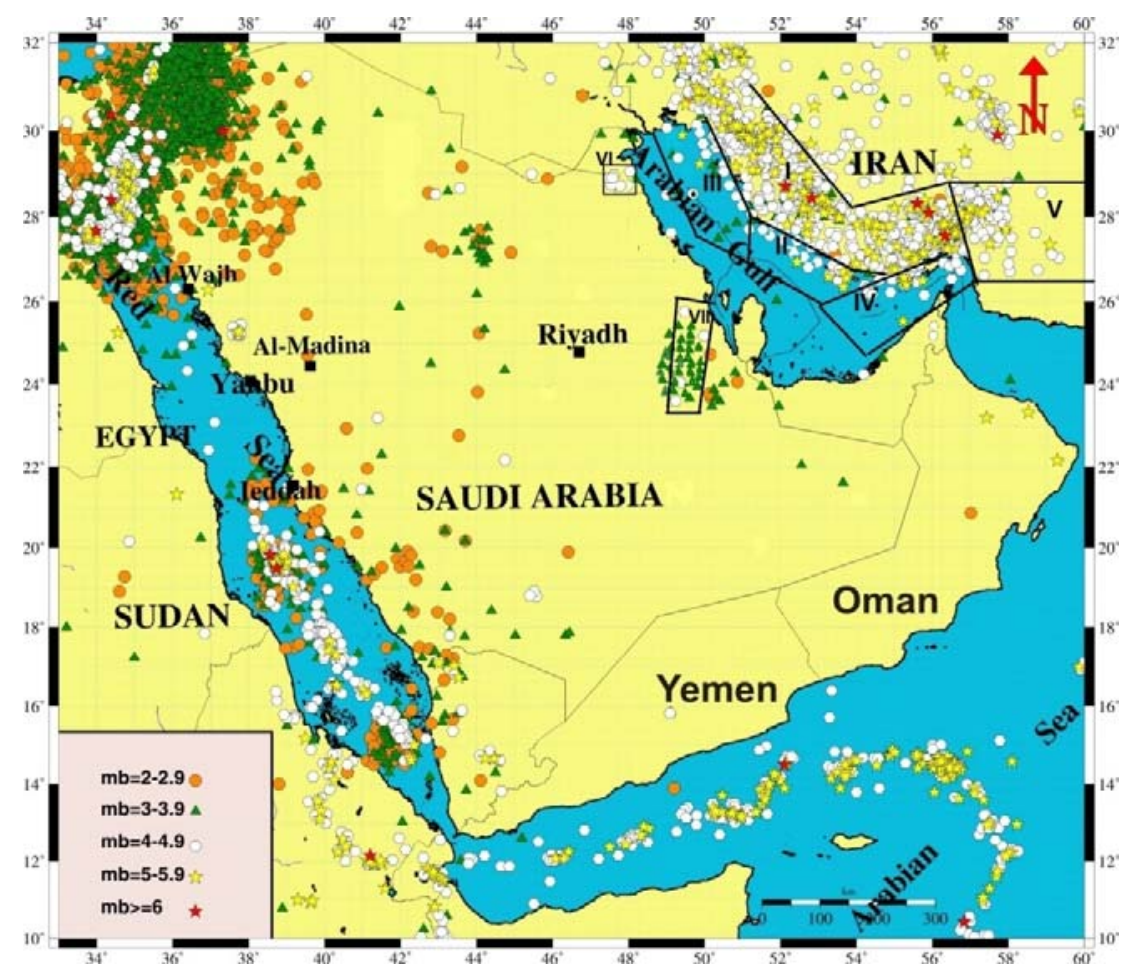

Figure 4: Seismic source zones affected the eastern province of Saudi Arabia. 
Table 1: $\quad$ Seismtectonis source zones affecting the eastern province.

\begin{tabular}{|c|c|c|c|}
\hline Zone & Source Zone Name & $\mathbf{M}_{\max }$ & b-values \\
\hline I & Zagros fold and thrust Belt & 7.4 & 1.00 \\
\hline II & Zagros Foredeep zone & 7.2 & 0.85 \\
\hline III & Zagros Mesopotamian Foredeep & 6.9 & 0.85 \\
\hline IV & Dibba Fault Line zone & 6.7 & 0.8 \\
\hline V & Makran subduction zone & 8.5 & 1.00 \\
\hline VI & $\begin{array}{c}\text { Southwestern Kuwait (Minagish- } \\
\text { Umm Qudair) zone }\end{array}$ & 6.5 & 0.74 \\
\hline VII & Al-Ghawar uplifting zone & 5.5 & 0.63 \\
\hline
\end{tabular}

Makran subduction zone located away of the eastern province and there is no direct damaging effects can be affected the buildings and industrial compounds in the area. Some of the identified seismic source zones described in the following paragraphs;

\subsubsection{Zagros Fold and thrust zone (ZFTZ)}

The Zagros mountain belt is a NW-trending fold-and-thrust belt, consisting of a 6-15-km thick sedimentary section which overlies Precambrian metamorphic basement while, the sedimentary cover can be divided into three successive sequences. The earthquake locations in this folded belt define a zone of about $200 \mathrm{~km}$ wide that runs parallel to its central axis. The present faulting activities beneath the Zagros fold belt as due to re-activation of pre-existing normal faults as reverse faults in the Arabian continental margin.

The historical data indicates that an earthquake of magnitude 5.7 has occurred in March 21 1875. One of earthquakes with magnitude of 5.5 occurred on Feb 4, 1934, and 3 events have magnitudes of 5.4 in 1925, 1939, and 1958 have occurred in this source zone. In 1972, a magnitude 6.1 has occurred which was followed by a magnitude 6 in 1976 over a period of 4 years. Magnitude range through this zone is seen to be frequented many times with magnitude 5 and above has been recorded. These earthquakes could indeed cause a significant ground shaking in the eastern province of Saudi Arabia. The $\mathrm{M}_{\max }$ of this zone is 7.4 .

\subsubsection{Zagros foredeep zone}

Zagros fold-thrust belt can be divided into three tectonic zones from NE to the SW into; Zagros fold-thrust belt, Zagros Foredeep zone and Zagros Mesopotamian Foredeep zone. The Zagros Foredeep Fault separates the alluvial basin of the Zagros Belt from the simply Folded Belt. It partly controls the morphology of the Arabian Gulf and is marked by relatively long linear anticlines. Seismically, the Foredeep fault is active but less than the Fold-thrust belt (Talebian and Jackson [11]). The foredeep Zagros system is limited to the coastal Plain and Arabian Gulf. The Coastal Plain is narrow feature that slopes gently to the south with an area of about $226.000 \mathrm{~km}^{2}$; the Arabian Gulf is a 
shallow epicontinental sea with a tectonic origin (foreland depression) which covers the Arabian shelf platform with water depths less than $100 \mathrm{~m}$. The evolution of the area can be subdivided into 3 main steps; The first step is characterized by a rifted continental shelf phase (Permian and Triassic) with thick marine deposition followed by thinning due to uplift and pre-Jurassic truncation associated to drift separation of the Arabian Plate. In the second step (Jurassic to Mid Cretaceous), thin sequences of arid climates were deposited. The third step concerns the collision and Zagros orogeny; at first a regional uplift is recognized in the whole area while in the Palaeocene-Eocene the subsidence starts and the first flysch sediment are deposited in an elongate foredeep with $\mathrm{NW} / \mathrm{SE}$ direction.

\subsubsection{Dibba fault line zone (DFLZ)}

The tectonic activities through this source zone are comes from the Dibba fault and the Hormuz salt basin south of the Arabian Gulf. This seismic source is active through both of historically and instrumentally periods. Two of earthquakes (magnitude 6.4 occurring in Jan 10, 1897 and in July 9, 1902) were documented. Furthermore, two of earthquakes with magnitude of 6.2 have also occurred in March 21, 1977 and Apr 1, 1977. It is revealed that this seismogenic source zone has earthquakes of above magnitude 6 and some seismic events above magnitude 5. The maximum earthquake of this zone is 6.7 based on the statistical analysis of the historical and instrumental data.

\subsubsection{Eastern province (Al-Ghawar) zone}

The Ghawar anticlinal structure has two of subparallel and north-south trending structural crests separated by a saddle with about 174 miles long and 12 miles wide. The general trend of this zone is oriented almost NNE-SSW. To the north there are N-S trending Kuwait Arch of basement horst. Al-Ghawar and Qatar arch area was subjected with some earthquakes with magnitudes greater than 5.0. Most of these seismic events are located south to southeast of the Ghawar anticlinal structure while others occurred to the west of Qatar peninsula. The most prominent joint set strikes northwest, and another set of less prominent oriented northeast. The growth of the Al-Ghawar anticlinal structure was active in the Pleistocene and Quaternary. The average growth rate, indicated by tilting of the flanks, is $0.06^{\circ}$ per one million years. The origin of these earthquakes is the extraction of oil and/or recent tectonic activities of the area.

\subsubsection{Southwestern Kuwait (Minagish-Umm Qudair) zone}

Recent seismicity studies for the State of Kuwait, reveals two main clusters of events. The first one is located around the Minagish-Umm Qudair oil fields in the south whereas, the second is concentrated at the Raudhatain-Sabriya oil fields in the north. The spatial distribution of earthquakes around the oil fields suggests that, these seismic events are of induced-tectonic origin. The magnitude of these earthquakes ranges from 0.3 to 4.8 and originated at depth levels ranged from 3.3 to $28 \mathrm{~km}$. The maximum expected magnitude of the southwestern Kuwait zone is 6.5 (El-Enezi et al. $[12,13])$. 


\section{Ground motion attenuation characteristics}

Peak Ground Acceleration (PGA) and response spectra represent the main parameters for seismic hazard assessment and designing earthquake resistant structures. Due to the absence of strong ground motion records for the eastern province of Saudi Arabia and even for the countries of the Arabian Peninsula, the previous hazard studies in Saudi Arabia (Al-Haddad et al. [14] and Al-Amri et al. [15]); Kuwait (Sadek [16]); United Arab of Emirates (Abdalla and AlHomoud [17, 18]) and for the Arabian Peninsula region (Peiris et al. [19]) borrowed attenuation models from abroad to calculate the ground motion parameters. This work has been oriented to have a simple approach for estimation of the ground motion attenuation relation for the considered area. This will be achieved throughout selection of an adapted seismological model for synthetic generation of PGA based on the stochastic approach taking into account the effect of probable variability in stress drop, radiation coefficient, cutoff frequency and focal depth.

\subsection{Seismological model}

Seismological model of Boore [20] have been applied worldwide for ground motion prediction. Fourier amplitude spectrum of ground acceleration at the bedrock is expressed as:

$$
A(f)=C S(f) D(f) P(f)
$$

where $S(f)$ represents the source spectral function, $D(f)$ is the path function characterizing the attenuation, $\mathrm{P}(\mathrm{f})$ is a filter to shape acceleration amplitudes beyond a high cut-off frequency $\left(\mathrm{f}_{\mathrm{m}}\right)$ to correspond the particular ground motion measure of interest, and $\mathbf{C}$ is a scaling factor. The single corner frequency model of Brune [21] is used in this study in the form of;

$$
\left.S(f)=(2 \pi f)^{2} M_{0} / \mid 1+\left(f / f_{c}\right)^{2}\right\rfloor
$$

where $\mathbf{M}_{\mathbf{0}}$, is the seismic moment and $\mathbf{f}_{\mathbf{c}}$ is the corner frequency which can be calculated throughout the following equation;

$$
f_{c}=4.9 \times 10^{6} V_{s}\left(\Delta \sigma / M_{0}\right)^{1 / 3}
$$

where Vs is the shear wave velocity at the source region that depends on the depth of the earthquake and the used crustal structure and $\Delta \sigma$ is the stress drop. The diminution function $\mathrm{D}(\mathrm{f})$ of Boore [20] can be defined as:

$$
D(f)=G \exp \left[-\pi f R / V_{s} Q(f)\right]
$$

where $\mathbf{G}$ represents the geometric attenuation while, the other term expresses anelastic attenuation and $\mathbf{Q}$ is the quality factor of the region. The high-cut filter in the seismological model is given by:

$$
P\left(f, f_{m}\right)=\left[1+\left(f / f_{m}\right)^{8}\right]^{-1 / 2}
$$


where $\mathbf{f}_{\mathbf{m}}$ controls the high frequency fall of the spectrum. The scaling factor $\mathbf{C}$ can be estimated as;

$$
C=R_{\theta \varphi} K F /\left(4 \pi \rho V_{s}^{3}\right)
$$

where $\mathbf{R}_{\boldsymbol{\theta} \boldsymbol{\varphi}}$ is the average radiation coefficient for range of azimuths and take-off angles, $\mathbf{K}$ is a factor for the partition onto two horizontal components, $\mathbf{F}$ is the free surface effect for the shear wave, $\boldsymbol{\rho}$ is the density at the source. The three segments geometrical spreading operator of Atkinson and Boore [22] has been used in this study. The geometrical attenuation term $\mathbf{G}$ for the eastern province is taken to be equal to $\mathrm{R}-1$ for $\mathrm{R}<70 \mathrm{~km}$ and equal to $\mathrm{R} 0.0$ for distances from 70 to $130 \mathrm{~km}$. The simulation procedure consists of three steps. First, a Gaussian stationary random process sample of strong ground motion duration that can be simulated as;

$$
T=1 / f_{c}+0.05 R
$$

Second, the sample is windowed by multiplying it with the modulating function of and is Fourier transformed into frequency domain. The Fourier amplitude spectrum is normalized by the square root of the mean square amplitude spectrum and multiplied by the target spectrum A(f) that was derived from the seismological model. Third, the transformed amplitude back into the time domain to generate a sample of acceleration time history.

\subsection{Ground motion attenuation model}

The attenuation model is generally expressed as a mathematical function connecting the strong ground motion to parameters characterizing the earthquake source, propagation medium, and local site response. The model should be simple as the available data and usually do not warrant excessive statistical analysis. Number of attenuation models is used for predicting strong ground motion in terms of magnitude, distance, and local site geology. The proposed model of Joyner and Boore [23] has been selected for this study where, the basic form of this model can be expressed as:

$$
\log (A)=\alpha+\beta M-\log R+b R+P \sigma
$$

where A represents the peak ground acceleration in gal $\left(\mathrm{cm} / \mathrm{s}^{2}\right) ; \mathrm{M}$ is the earthquake magnitude; $\mathrm{R}$ is the distance; and $\alpha, \beta$, and $\mathrm{b}$ are the model parameters. $\sigma$ is the standard deviation of $\log (\mathrm{A})$. The factor $\mathrm{P}$ is a dummy variable that represents the normal distribution: a value of $\mathrm{P}=0$ implies mean (50-percentile) values of PGA, while the value of $\mathrm{P}=1$ implies mean plus one standard deviation (84-percentile) values. The above-mentioned equation is a linear function of magnitude and of distance dependent terms. The first term represents the geometric losses, and it is constrained to spherical spreading from a point source while the second term accounts for anelastic losses. Joyner and 
Boore [23] performed the regression analyses on the attenuation model in two stages; the first regression is on distance as:

$$
\log (A)=\sum_{i=1}^{n} a_{i} E_{i}-\log R+b r
$$

where $E_{i}=1$ for earthquake I and 0 otherwise.

$\mathrm{A}$ is the peak horizontal acceleration, $\mathrm{n}$ is the number of earthquakes included in the data set; $d$ is the closest distance between the recording site and the surface projection of the fault rupture and values of $\alpha_{i}$ and $b$ are determined by linear regression with average depth. Once the $\alpha_{\mathrm{i}}$ values are determined, they are used to calculate the first order polynomial regression representing the magnitude dependence. The second regression is then performed to determine the magnitude dependence:

$$
a_{i}=\alpha+\beta M_{i}
$$

The employing of dummy variable $E_{i}$ has the advantage that it decouples the determination of magnitude dependence from the determination of distance dependence.

Through this work, the essential model parameters of stress drop, focal depth, corner frequency $\left(\mathrm{f}_{\mathrm{m}}\right)$, and the radiation coefficient are treated as random variables but were distributed uniformly around the mean value. The stress drop is taken to vary between 20 and 60 bars. The average focal depth for the affected zones (Zagros Foredeep, Zagros Mesopotamian Foredeep seismic source zones) has been estimated to be $25 \mathrm{~km}$ while, the focal depth of southwestern Kuwait seismic source (the closest seismic source to the eastern province of Saudi Arabia) ranges from 3.3 to $28 \mathrm{~km}$. Accordingly, the used focal depth through this study is taken as a uniform random variable in the range of $3.0-28 \mathrm{~km}$. The cutoff frequency is taken in the interval $20-30 \mathrm{~Hz}$. The range of the S-wave radiation coefficient is taken as 0.48-0.64 (Boore and Boatwright [24]). Q value has been calculated by Mokhtar et al. [25] for the eastern part of the Arabian platform.

PGA values for the eastern province of Saudi Arabia are simulated for moment magnitudes ranging from 4.0 to 6.5 with 0.5 magnitude unit increments (Fig. 5). The upper bound of magnitude range is selected to be 6.5 representing the maximum magnitude that can be produced from southern Kuwait seismogenic source. The distance is varied from 0 to $300 \mathrm{~km}$ (at 18 values of fault distances ranging from 1 to $300 \mathrm{~km}$ as follows: 1, 2, 5, 10, 15, 20, 30, 40, $50,60,70,80,100,120,150,200,250$ and $300 \mathrm{~km}$ ) representing the shortest distance between the projection of the rupture and the site of interest. The parameters of the attenuation equation for bed rock as follows;

$$
\log (\mathrm{A})=-0.94+0.249 \mathrm{M}-\log \mathrm{r}-0.00233 \mathrm{r}+0.19 \mathrm{P}
$$

The local geology and topography effects control the distribution of damages due to strong earthquakes. The amplification of earthquake ground motion by local site conditions must be estimated in areas characterized by soft sediments. 


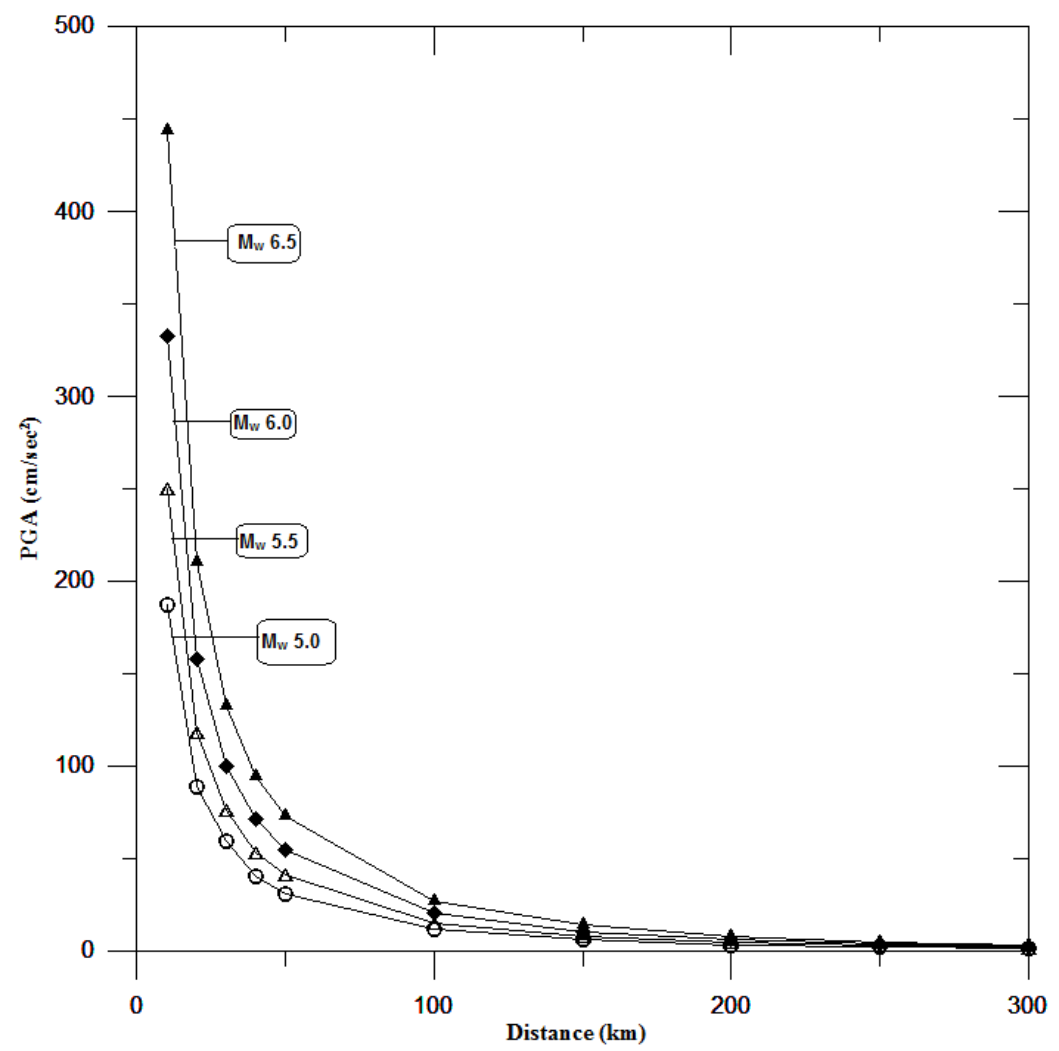

Figure 5: The estimated PGA through the eastern province of Saudi Arabia.

\section{Conclusions}

Eastern province of Saudi Arabia attracted the attention recently of multinational companies working in the development of petroleum industries however number of earthquake prone zones surrounded the area. Hence, there is a wide-spread potentiality of seismic hazard due to these earthquakes are expected. Accordingly, the estimation of ground motion attenuation relation that represents the essential element to quantify the seismic hazard for the considered area is of national importance. The present study acts as step through the national plan aims to sustain development through all ways of life. The results of this work must be taken into consideration through the National building Code committee and following-up of implementation of these results are highly recommended.

\section{References}

[1] Kanamori, H. (1986): Rupture process of subduction-zone earthquakes. Ann. Rev. Earth. Planet. Sci., 14, pp. 293-322. 
[2] Al-Sayari, S. S. \& Zoetl, J. G. (eds) (1978): Quaternary Period in Saudi Arabia. Sedimentological, Hydrogeological Hydrochemical, Geomorphologicaland Climatological Investigations in Central and Eastern Saudi Arabia. Springer-Verlag, Vienna.

[3] United States Geological Survey (USGS) (1963): Geologic Map of the Arabian Peninsula (Scale 1:2,000,000) and Geologic Quadrangle Maps (Scale 1:500,000).

[4] Clarke, H. W. M. (1988): Stratigraphy and rock unit nomenclature in the oil-producing area of interior Oman. Journal of Petroleum Geology, II(1): 5-60.

[5] Al-Shaabi, S. F. (2004): Induced seismicity at Ghawar hydrocarbon reservoir, eastern Saudi Arabia. Annals Geol. Surv. Egypt, V. XXVII, pp. 335-342.

[6] Scordilis, E.M. (2006): Empirical global relations converting $\mathrm{M}_{\mathrm{s}}$ and $\mathrm{M}_{\mathrm{b}}$ to moment magnitude. Journal of Seismology, 19, 225-236.

[7] Gardner, J.K. and Knopoff, L. (1974): Is the sequence of earthquake in Southern California, with aftershocks removed, Poissonian? Bull. Seism. Soc. Am., 64: 1363-1367.

[8] Al-Amri, A. M. (2004): Seismic zones in the Arabian Peninsula. Seismic Studies Center, King Saud University, Riyadh, Saudi Arabia, p.215

[9] Tavakoli, B. (1996): Major Seismotectonic Provinces of Iran. International Institute of Earthquake Engineering and Seismology, Internal Document, Tehran, Iran.

[10] Pascucci, V., Free, M.W., and Lubkowski, Z.A. (2008): Seismic hazard and seismic design requirements for the Arabian Peninsula. The $14^{\text {th }}$ World Conference on earthquake engineering, October 12-17, Beijing, China.

[11] Talebian, M.; Jackson, G. (2004): A reappraisal of earthquake Focal mechanisms and active shortening in Zagros mountain of Iran. Geophys. J. Int., 156, 506-526.

[12] Al-Enezi, A., Abdul Fatah and Safak E. (2005): Assessment of the seismic hazard for the state of Kuwait. Abstracts of the Gulf Seismic Forum, UAE University, Al-Ain, U. A. E.

[13] El-Enezi, A., Petrat, L., and Abdel-Fattah, R. (2008): Induced seismicity and surface deformation within Kuwait's oil fields. $2^{\text {nd }}$ IASME/WSEAS International conference on geology and seismology (GES'08), Cambridge, UK, February 23-25.

[14] Al-Haddad, M. Siddiqi, G. H., Al-Zaid, R., Arafa, A., Necioglu, A., and Turkelli, N. (1994): A basis for evaluation of seismic hazard and design criteria for Saudi Arabia. Earthquake Spectra 10 (2), 231-258

[15] Al-Amri, A., Rodgers, A., and Al-khalifah, T. (2008): Improving the Level of Seismic Hazard Parameter in Saudi Arabia Using Earthquake Location. Arabian J. of Geosciences, 1, DOI 10.1007/s12517-008-0001-5, 1-15.

[16] Sadek, A. W. (2004): Seismic map for the state of Kuwait. Emirates Journal for Engineering Research, 9 (2), pp. 53-58. 
[17] Abdalla, J.A \& A.S. Al-Homoud (2004a): Seismic hazard assessment of United Arab Emirates and its surroundings. Journal of Earthquake Engineering, Vol. 8, No. 6, 817-837.

[18] Abdalla, J.A. and Al-Homoud, A. (2004b): Earthquake hazard zonation of eastern Arabia. Proceedings of the 13th World Conference on Earthquake Engineering, Vancouver, Canada, August 1-6, 2004, Paper No. 1008.

[19] Peiris, N.; Free, M.; Lubkowski; Z. and Hussein, A.T. (2006): Seismic hazard and seismic design requirements for the Arabian Gulf region. Proceedings of the 1st European Conference on Earthquake Engineering and Seismology, Geneva, September 2006, Paper No. 1121.

[20] Boore, D.M. (2003): Simulation of ground motion using the stochastic method. Pure \& Appl. Geophys., 160:635-675.

[21] Brune, J. (1970): Tectonic stress and the spectra of seismic shear waves from earthquakes. J Geophys Res 75:4997-5009.

[22] Atkinson G.M., Boore D.M. (1995): Ground-motion relations for eastern North America. Bull Seism Soc Am 85:17-30.

[23] Joyner, W.B. and Boore, D.M. (1981): Peak horizontal acceleration and velocity from strong motion records including records from the 1979, Imperial valley, California earthquake. Bull Seism Soc Am 71:2011-2038.

[24] Boore, D.M. and Boatwright, J. (1984): Average body-wave radiation coefficients. Bull Seism Soc Am 74:1615-1621.

[25] Mokhtar, T. A., C. J. Ammon, R. B. Herrman, and H. A. A. Ghalib (2001): Surface-wave velocities across Arabia, Pure Appl. Geophys., 158, 1425 1444. 